\title{
Opinion of Startups in Exemplifying Role of Business Incubators in Sustaining their Survival and Growth: Empirical Evidence from Pakistan
}

\author{
Nasir Mahmood ${ }^{1 *}$, Cai Jianfeng ${ }^{1}$, Hina Munir ${ }^{1},{\text { Nosheena } \text { Yasir }^{2} \text { and Farhan Jamil }}^{3}$

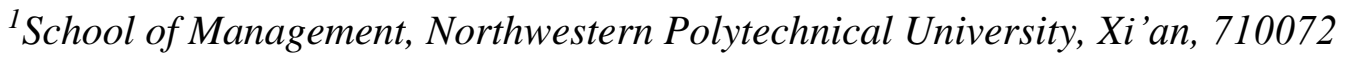 \\ Shannxi, P.R.China \\ ${ }^{2}$ Northwest university Xi'an710069, Shannxi, P.R.China \\ ${ }^{3}$ Department of Management, Universiti Teknologi Malaysia, 81310, Malaysia \\ *nasirmahmood@mail.nwpu.edu.cn
}

\begin{abstract}
The purpose of this paper is to examine the role of business incubators in sustaining the growth and survival of startups. In addition, this study aims to explore how business incubators provide different facilities to startups and the effectiveness of these services and facilities. Business incubation systems in Pakistan are in their early stages and face several issues. This study focuses on developing a better understanding of business incubators. The standardized questionnaire technique is used to gather information on all areas of concern pertaining to startups by focusing on their survival and growth. The scale used in the questionnaire is the five-point Likert scale. The research sample of this study comprises startups located at seven business incubators - Plan9, Plan10, LUMS, NSPIRE, NUST, UETP and PASHA. The findings of the study reveal that the incubation facilities, financing, technology $R \& D$, sources of $R \& D$, joint $R \& D$ projects, network opportunities, $R \& D$ projects, current benefits, and incubator business objectives have a significant positive relationship with incubator performance. All these factors facilitate measurement of the incubator's performance. Effective incubation of startups will help create new jobs and wealth. The results provide guidelines to business incubators to take necessary actions for the survival and growth of startups. This study has been conducted in collaboration with the founders of startups, and it is the first of its kind with respect to Pakistan.
\end{abstract}

Keywords: Business incubators, startups, growth, sustainability, Pakistan

\section{Introduction}

Business incubation is a progressive tool meant to support and grows a business in a particular community. It assists newly emerged businesses by rendering them different services and assistance such as marketing plans, space management, access to capital, and other professional services [1]. The business incubator industry came into existence in the United States in 1959 when a privately owned for-profit center was started in Batavia, New York in 1959 [2], and later flourished in Europe, South Korea, and other countries during the last-but-one decade of the twentieth century. Today, worldwide incubation programs comprise more than 7,000 incubators [3].

The National Business Incubation Association (NBIA) of the United States defines business incubation as a business support process that accelerates the successful development of start-up and fledgling companies by providing entrepreneurs with an array of targeted resources and services. These services are usually developed or orchestrated through incubator management, and offered at the business incubator's place itself as well as through its network of contacts. A business incubator's main goal is to 
produce successful firms that would leave the program as financially viable and freestanding entities. The incubator graduates should essentially have the potential to create jobs, revitalize neighborhoods, commercialize new technologies, and strengthen local and national economies [4].

The basic concept of a business incubator is to provide start-up firms with a range of resources and services related to inaugurating the firms [5-6].

Entrepreneurs need a place where they can obtain operational services economically to reduce start-up and growth costs. They also need to reduce the risk of failures. Furthermore, entrepreneurs seek to access world-class services and build on proven models [7].

Hatten describes a business incubator as an attractive place to start a new small-scale business. It offers support services and equipment such as photocopiers, fax machines, and computers, which young businesses often cannot afford to buy [8].

\section{Business Incubators in Pakistan}

In Pakistan, the idea of business incubation is quite novice and in the age of infancy. The main type of business incubators working in Pakistan are university-based business incubators. The prime goal of universities is to provide education. However, they can still make a comprehensive contribution to local, regional, and national economies by incorporating innovation, research, and technology transfer to the industry $[9,10]$. Of course, there are some operational university-based incubators in Pakistan that help their students and industries with their innovations. The incubators functioning with the ambit universities have the same mechanism and infrastructures as the common incubators. However, currently, university-based incubators have some extraordinary traits compared to common incubators, such as generation of employment opportunities for their students and support for the private sector until the time of their ultimate graduation [11]. Some of the key universities and higher education institutions have come forward and established university-based incubators in Pakistan [12].

Table 1. Some Examples of UBls in Pakistan

\begin{tabular}{|l|l|l|l|}
\hline \multicolumn{1}{|c|}{ University } & \multicolumn{1}{c|}{ Location } & \multicolumn{1}{c|}{ University } & \multicolumn{1}{c|}{ Location } \\
\hline $\begin{array}{l}\text { University of } \\
\text { Agriculture }\end{array}$ & Faisalabad & $\begin{array}{l}\text { Institute of Business } \\
\text { Administration, }\end{array}$ & Sukkar \\
\hline $\begin{array}{l}\text { University of } \\
\text { Engineering \& } \\
\text { technology }\end{array}$ & Peshawar & $\begin{array}{l}\text { Quaid-e-Azam, } \\
\text { university }\end{array}$ & Islamabad \\
\hline $\begin{array}{l}\text { University of } \\
\text { Veterinary and } \\
\text { Animal Sciences }\end{array}$ & Lahore & $\begin{array}{l}\text { University of } \\
\text { Engineering \& } \\
\text { Technology }\end{array}$ & Lahore \\
\hline $\begin{array}{l}\text { LUMS Centre for } \\
\text { Entrepreneurship }\end{array}$ & Lahore & $\begin{array}{l}\text { Malakand } \\
\text { University, Swat }\end{array}$ & Swat \\
\hline
\end{tabular}

Another kind of incubator working in Pakistan is the technology-based incubator, which is an entity that supports and helps gear up innovation. It blends technology, resources, and preliminary knowledge to improve entrepreneurial talent, speed up the progress of newly established businesses, and consequently improve the commercialization of technology [13]. Table 2 explains the some examples of TBIS in Pakistan [12]. 


\section{Table 2. Some Example of Technology Business Incubators}

\begin{tabular}{|l|l|}
\hline Technology Incubation center & Location \\
\hline NUST & Islamabad \\
\hline Plan9 Tech Incubator & Lahore \\
\hline COMSATS & Islamabad \\
\hline Institute of Space Technology & Islamabad \\
\hline
\end{tabular}

The third type of incubator is industrial incubator. Commonly, industrial business incubators are nurseries meant for the nourishment of new businesses and their establishment. However, these are primarily aimed at emergence of the industrial era at the medium and small level. Likewise, there are no limitations regarding the admission into the incubation. In Pakistan, there are three industrial business incubators and all are under the control of the government. Normally, these incubators give suggestions to the government about industry requirements, solutions to industry issues, and identifying industries that need economic development $[12,36]$.

Table 3. Some Examples of Industrial Business Incubators

\begin{tabular}{|l|l|}
\hline \multicolumn{1}{|c|}{ Industrial Incubators } & Location \\
\hline Small \& Medium Enterprise Development Authority & Lahore \\
\hline National Industrial Parks Dev. \& Mgmt. Company & Karachi \\
\hline PCSIR Laboratories Complex & Karachi \\
\hline
\end{tabular}

Seven incubators were selected in this study for the purpose of judging the opinion of startups and understanding the role of business incubators in sustaining their growth and survival - Plan9, PLAN 10, PASHA, NSPIRE, NUST, UETP and LUMS. Plan9 is Pakistan's largest technology incubator and an initiative launched in 2012 by the Punjab government, Plan10 is an initiative of Plan9, NSPIRE is an IT-based technology incubator established in 2015, Pakistan Software Houses Association (PASHA) is a trade body and a registered association for IT and ITES (P@SHA) established in 1992, and LUMS is a center for entrepreneurship established in 2014.

The objective of this paper is to assess the role of an incubator, the services provided by the incubator to startups, and their effect on sustaining startups' growth and survival. Questions covering different dimensions were posed to different startups incubated by incubators. The services include i) the facilities provided by the incubator within the incubation program; ii) planning; iii) financial support that is crucial for survival and growth; iv) technology R\&D; v) sources of R\&D; vi) incubator support in university linkages; vii) network opportunities; viii) startups' opinion about incubators' performance; ix) public and private support; and x) business incubators' objectives and benefits offered to startups, as well as public and private support available to startups.

\section{Literature Review}

Business incubators are considered as centers meant to support startup businesses and sustain their survival by rendering effective managerial and technical assistance in the field of marketing, planning, finance, and other concerns of the businesses. This assistance and support can be professional as well as non-professional. The supports services and assistance are provided to the businesses during their initial period of establishment and their age of infancy. This scenario helps the businesses to concentrate on their business plan and development, thus leading to a rise in their success rate [14]. 
National Business Incubation Association (2009) defines "Business incubation is a business support process that accelerates the successful development of start-up and fledgling companies by providing entrepreneurs with an array of targeted resources and services. These services are usually developed or orchestrated by incubator management and offered both in the Business Incubator and through its network of contacts. A Business Incubator's main goal is to produce successful firms that will leave the program financially viable and freestanding" [15].

Business incubation is one of the tools that lead towards the creation new opportunities for innovation and entrepreneurship. The concept of business incubation has gained worldwide popularity by rendering favorable environment for the progress of SMEs. Incubators are considered as a means of providing special business progressive services by providing services through innovation

Business incubators (BI) are a unique combination of people, space and business development processes [16]. The ultimate goal of business incubators is to support nascent companies and entrepreneurs until they become sustainable businesses [17], and contribute to job and wealth creation (NBIA, 2007). Usually property-based [18], BIs provide their clients with specialized services such as flexible space, shared equipment, administrative services, granting them networking opportunities and access to venture capital $[1,13]$.

Incubators provide their clients with basic infrastructural support, such as shared office facilities and workshops, as well as business assistance services. Incubators also provide technology-related support including technology transfer programs to their tenant firms [19-20]. Apart from providing basic services and resources to the fledgling venture, the incubator plays a critical networking role in many cases by linking talent, technology and capital so as to accelerate the development of a new firm. Second generation incubators that are run by a mixed group of sponsors are more likely to have enterprise-oriented managers interested in developing human capital [21].

Business incubators offer support and assistance to newly established business firms to ensure their survival and growth during the startup periods by providing them technological innovations and integrated services [22-23]:

$>$ Incubators provide office and production space on flexible and affordable terms to support newly established business.

$>$ Incubators utilize highly technical and threshold measures to select firms for incubation. This exerts a significant impact through innovation and progress. As a common practice, newly established firms depend on incubators, what is being provided by them, and how they are being evaluated [6,24]. Exit criteria are not as complicated as the entry criteria. Usually, for ensuring a normal and reasonable turnover, the limits of tenancy lie between a periods of three to five years.

$>$ Furthermore, incubators offer access to financial resources through the support of business angles, investors and capitalist and companies [25] in addition to other services such as enterprise counseling and training, R\&D and risk capital, and assistance with product development and marketing.

$>$ Business incubators provide presentation skills that help attract customers and sometime search for investors [26].

$>$ Practitioners often tout the benefits of BIs in supporting new ventures [27-28]. BIs have a potential effect on long- term survival and subsequent growth of firms since they provide a comprehensive service portfolio to nascent companies.

$>$ Incubators support small enterprises and emerging venture by rendering technical services, management assistance, mentoring, and other assistance in developing their business [29-30]. Incubators develop entrepreneurial processes for new venture creation, and contribute toward their success [31-32,20,33-34]. 
$>$ Business incubators support the newly established business firms by offering them an effective and productive mechanism. The intent is to reduce their probability of failure during their infancy age [21].

$>$ This facilities that incubators provide to startups includes Furnished office equipment, IT equipment's (laptops, printers, fax), Telephone, High speed internet, Access to financial capital, assistance in business plan development, Linkages with academia and industry, Networking with local and international Stakeholders, Assistance in legal documentation, Trainings and workshop, Stipend/Salary of incubates team start-up firms are characterized by newness and resource poverty [17]. They often lack technical and marketing capabilities, and have limited access to financial supports [13]. These can lead to failure of many start-ups $[13,35]$.

\section{Research Methodology}

To validate the following hypotheses the research methodology adopted is hereunder:

H1: There is significant relation among Facilities, Finance, Technology R\& D, Sources of R \& D, Joint R\&D, Network opportunities, R\&D projects, Business current benefits, Business incubator objective and incubator performance.

H2: There is significant association among the Facilities, Finance, Technology R\& D, Sources of R \& D, Joint R\&D, Network opportunities, R\&D projects, Business current benefits, Business incubator objective and incubator performance.

H3: Incubator performance has significant impact on facilities, finance, technology R\& $D$, sources of $R \& D$, Joint $R \& D$, network opportunities, $R \& D$ projects, business current benefits, Business incubator objective.

Quantitative approach: The research methodology primarily adopted a quantitative approach, wherein a questionnaire technique was used to collect data from all new startups in the business incubators located in Pakistan, including NSPIRE, LUMS, Plan9, Plan10, PASHA, NUST, and UET (P).

Sampling technique: In this paper, the convenience sampling method of nonprobability sampling is used. According to Kotler and KL (2006) the reason behind applying this technique could be respondents' easy accessibility and availability.

Data collection: The questionnaire survey was filled by all startups currently working in the business incubators in Pakistan. Data was collected through personal visits to these starts ups.

Data analysis: Data was analyzed through SPSS 20. The analyses include the demographics of startup correlation, chi-square, and regression analysis.

\section{Analysis and Results}

This segment consists of three sections. Section one explains the demographics of the startups covered in the study. The second section pertains to the questionnaire analysis and the responses of the startups about the different facilities and services provided by the incubator. The third section is about the correlation analysis of different services and facilities provided by incubators to startups, which affect their survival and growth.

\subsection{Response Rate}

In this paper the total of 100 questionnaires was distributed to 7 business incubators located in different areas of Pakistan; which are NSPIRE, PLAN 9, PLAN10, NUST, UET (PESHAWAR), PASHA and LUMS. The results shows the total of 83 questionnaires are those which was useful for the study which shows the number of PLAN 9 (17), LUMS (12), NSPIRE( 12), UETP ( 10), PLAN 10 (12), PASHA( 11) and NUST (9), Figure 1 also depict that result. 


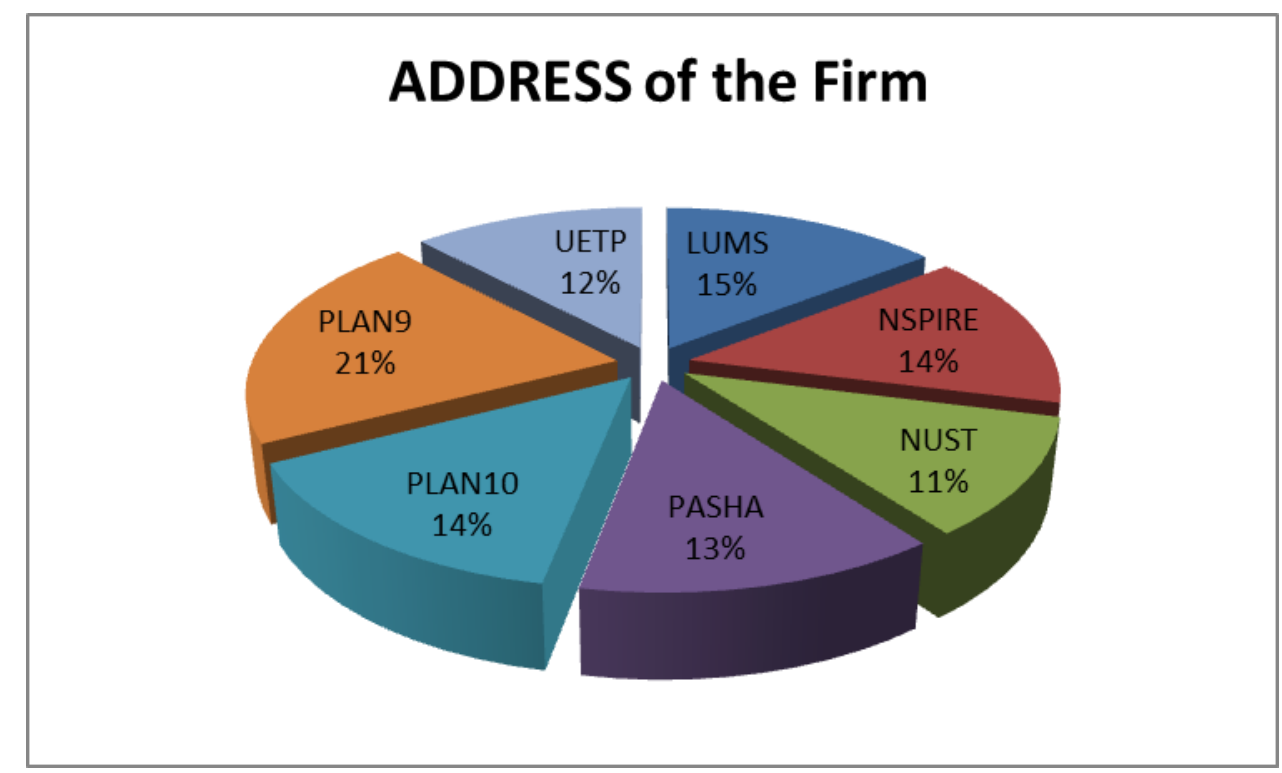

Figure 1.

\subsection{Demographic Analysis}

The demographic analysis shows the basic details about the startups, which includes the job title, age, highest qualification, position, questions about the website, business founded, ownership structure, people working in the business, and geographical distribution of services. The results of the study showed that most of the respondents held the job title of CEO and they belonged to the age group of 26-33 years (44.6\%). The majority of them had the highest degree of masters (47\%). Their position in the business was majorly of owners (72.3\%), and they had their own website. The time span of business founded was less than 1 year $(59 \%)$. Most businesses were owner managed (41\%), run by mostly $1-5$ members (59\%). Furthermore, most of the businesses were operating locally $(68.7 \%)$.

The different services discussed in this study include facilities, finance, technology $R \& D$, sources of $R \& D$, joint $R \& D$ efforts, network opportunities, $R \& D$ projects, incubator performance, current benefits, and incubator objectives. The sub-items under facilities include furnished office equipment, IT equipment (laptops, printers, fax machines), telephone, high speed internet, access to financial capital, assistance in business plan development, linkages with academia and industry, networking with local and international stakeholders, assistance in legal documentation, trainings and workshops, and stipend/salary of team members. According to the results, most of the respondents showed a strong agreement with the facilities provided by the incubator. Financial resources provided by the incubator, which are helpful for survival and growth, include directors' own funds, parent company/center's financial support, family and/or friends, venture capitalist funds, business angels, chamber of commerce grants, bank loans, government grants, other public grants. Most of the respondents said the impact of financial resources on startup survival and growth was high, depending on their accessibility, while some of them said the impact was medium.

Technology R\&D includes questions about the products and processes which startup introduce, and which are in the form of an innovation, a significantly improved idea, or entirely new to the market. Most of the respondents said that their startup is producing similar products and processes.

Sources of R\&D that have an impact on startups' success include the company itself, suppliers, other companies, parent company, consultancies, and universities/research 
institutes. Most respondents said that the different sources have a high and medium impact on startup success. Joint $R \& D$ projects, their collaboration with universities, and impact on startups success. Joint R\&D projects, their collaboration with universities, and impact on startups encompass sub-items such as "brought in fresh point of view," "brought in expertise," "reduced development time" and "saved on cost". For all items, the respondents showed agreement.

Network opportunities provided by incubator to new startups include entrepreneurial network, entrepreneurial education, Tie to a university, Community Support, Government, Affiliation with financial institutions such as banks, Venture Capitals and Business Angels. Most of the items evoked an "agree" or "strongly agree" response from the respondents.

Benefits of joining a business incubator include sub-items such as help with financing, training, marketing, business planning, and management skills; contacts with other businesses; help from mentors; and access to business premises and shared facilities (e.g., secretarial, phone, internet, meeting rooms). Here as well, most results lied in the "agree" and "strongly agree" categories.

Business incubator objectives include contribution to local job creation, speed up commercialization, create new startups, increase patents and licensing, and secure research contracts from industries and institutes. Most of the respondents were inclined toward "agree" and "strongly agree."

\subsection{Reliability, Correlation, Regression and Chi Square Analysis}

Table 1 shows the reliability statistics of the different questions pose to the startups about the various services and resources of the business incubators. In table, facilities include the 11 items with the reliability of .732, finance includes the 18 items with reliability of .548 , technology $R \& D$ includes 8 items with reliability of .701 , sources $R \& D$ includes 6 items with reliability of .657 , joint $R \& D$ projects with the reliability of .795 , network opportunities with the reliability of .643 , R\&D projects with the reliability of .868 , incubator performance includes 11 items with the reliability of .703 , benefits to business with reliability of .915 and business incubator objectives includes 5 items with the reliability of .845 . Table I also shows the mean and standard deviation of the variables, depicting the tendency of the respondents about each phenomena. The respective mean and standard deviation values of facilities, finance, technology $R \& D$, sources of $R \& D$, joint $R \& D$ projects, network opportunities, $R \& D$ projects, incubator performance, business benefits, and incubator objectives are 1.9168, 1.8701, 1.2334, $1.8373,1.7711,2.0663,2.2557,1.3373,1.4150$, and 1.4819 , and $.53448, .24575, .23731$, $.46633, .66282, .50769, .80885, .20698, .48868, .48993$. Table I also shows the Pearson product-moment correlation coefficient values, which indicate that most of the variables have a significant correlation at $\mathrm{p}<0.01$ and $\mathrm{p}<0.05$.

Table 2 tells about the values obtained from the chi-square test - facilities: 31.494 ; finance: 20.241; TRD: 62.988; SRD: 15.7833; JRD: 31.024: NP: 47.241; RDP: 55.145; IP: 26.012; BCB: 65.012; and BIO: 85.578.

Table 3 describes the variation $(\mathrm{R}=80 \%)$ in facilities, finance, TRD, SRD, PPS, JRD, $\mathrm{NP}, \mathrm{REP}, \mathrm{BCB}$, and $\mathrm{BIO}$. The value of $\mathrm{R}$ square shows a $61 \%$ total variation in incubator performance due to predictor variables. The Durban Watson test was applied to check the nature of autocorrelation and the value obtained was less than 2 , indicating a positive autocorrelation.

Table 4 explains the value of the ANOVA results. From the significance value of $\mathrm{p}<0.05$, it is clear that all variables have a significant association with incubator performance.

Table 5 tells us about the values of standardized and unstandardized coefficients through which the value of dependent variable is changed due to the change in the 
independent variable. The table also explains the tolerance and VIF values. If the tolerance value exceeds 5 and VIF exceeds 10, then collinearity exists. As the table shows a tolerance value less than 5 and VIF value less than 10 , no collinearity exists.

Table 6 speaks about the response of the startups about the public and private support provided by the incubator. The first question is about the government grant available for the startups. The results showed that 64 respondents said yes and 19 said no. The second question is about financial programs that the startups had heard about; the responses showed 65 in favor of yes and 18 in favor of no. Furthermore, 74 respondents said that they have applied for a government grant, 61 respondents said they have received government grant, and 22 said they have not received it. A total of 66 respondents have applied for a government loan for startups, while remaining 17 have not. Of the total 83 respondents, 68 said that they have received government loans for startups, while the remaining 15 did not. Moreover, 63 respondents are members of the chamber of commerce. Of the total respondents, 71 said that they have visited the chamber of commerce. Additionally, 65 respondents said they have attended workshops, training programs, and seminars held by the chamber of commerce.

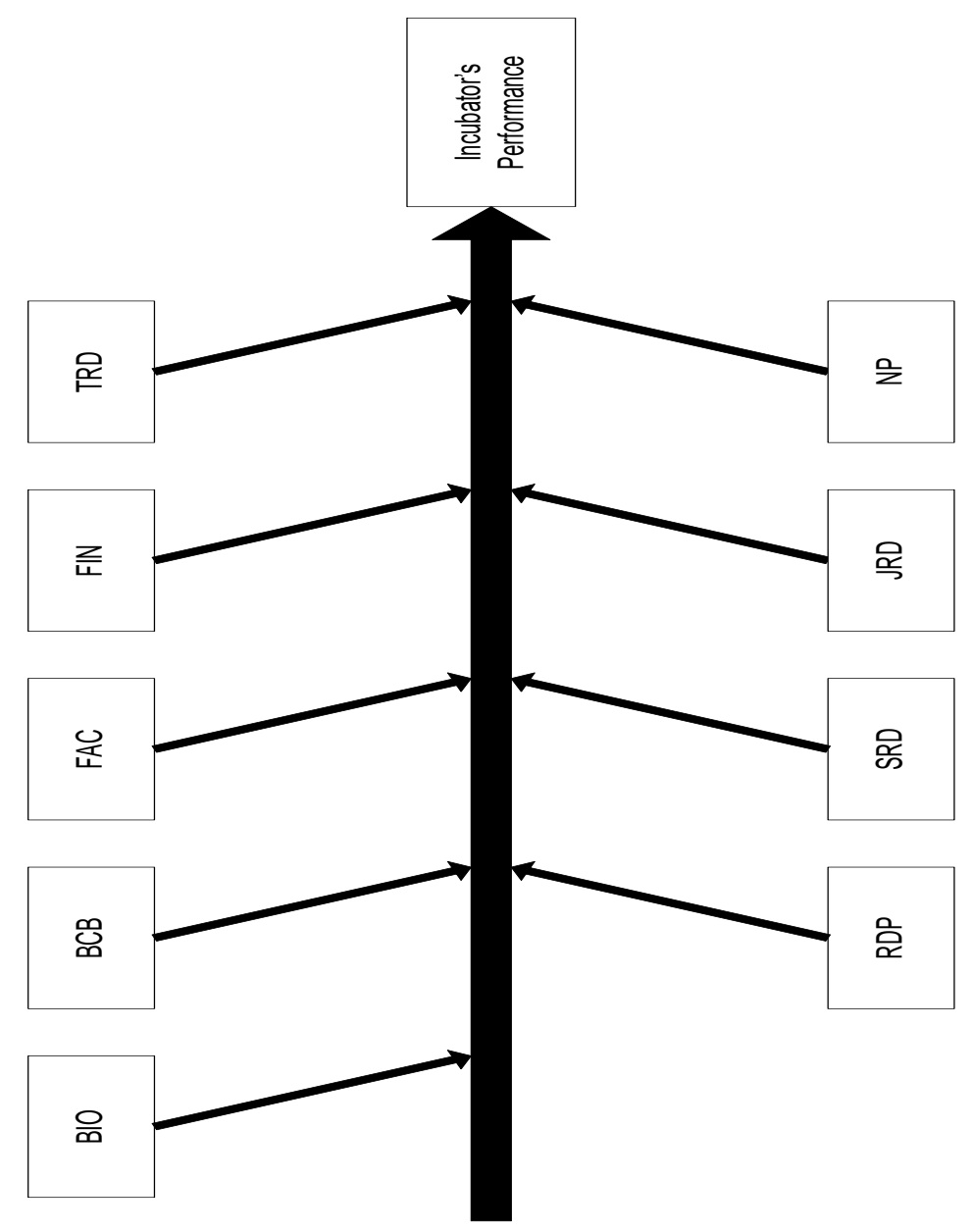

$\mathbf{F A C}=$ Facilities, $\mathbf{F I N}=$ Finance, $\mathbf{T R D}=$ Technology Research and Development, $\mathbf{S R D}=$ Sources of Research and Development, JRD=Joint R\&D, NP= Network Opportunities, $\mathbf{R D P}=\mathrm{R}$ and $\mathrm{D}$ Projects, $\mathbf{I P}=$ Incubator Performance, $\mathbf{B C} \mathbf{B}=$ Business Current Benefits, $\mathbf{B I O}=$ Business Incubator Objectives.

Table 4. Correlation. Mean, S.D., Alpha Statistics 


\begin{tabular}{|c|c|c|c|c|c|c|c|c|c|c|c|c|c|}
\hline $\begin{array}{l}\text { VARIA } \\
\text { BLES }\end{array}$ & $\begin{array}{l}\text { Me } \\
\text { an }\end{array}$ & S.D & $\begin{array}{c}\text { Reliab } \\
\text { ility }\end{array}$ & 1 & 2 & 3 & 4 & 5 & 6 & 7 & 8 & 9 & $\begin{array}{l}1 \\
0\end{array}$ \\
\hline FAC. & $\begin{array}{c}1.91 \\
68\end{array}$ & $\begin{array}{l}.534 \\
48\end{array}$ & .732 & 1 & & & & & & & & & \\
\hline FIN. & $\begin{array}{c}1.87 \\
01\end{array}$ & $\begin{array}{l}.245 \\
75\end{array}$ & .548 & $\begin{array}{c}.262 \\
*\end{array}$ & 1 & & & & & & & & \\
\hline TR\&D & $\begin{array}{c}1.23 \\
34\end{array}$ & $\begin{array}{l}.237 \\
31\end{array}$ & .701 & .055 & $\begin{array}{c}- \\
.148\end{array}$ & 1 & & & & & & & \\
\hline SRD & $\begin{array}{l}1.83 \\
73\end{array}$ & $\begin{array}{l}.466 \\
33\end{array}$ & .657 & $\begin{array}{l}.499 \\
* *\end{array}$ & $\begin{array}{l}.311 \\
* *\end{array}$ & $\begin{array}{c}- \\
.403 \\
* *\end{array}$ & 1 & & & & & & \\
\hline JRD & $\begin{array}{c}1.77 \\
11\end{array}$ & $\begin{array}{c}.662 \\
82\end{array}$ & .795 & $\begin{array}{c}.419 \\
* *\end{array}$ & $\begin{array}{c}.289 \\
* *\end{array}$ & $\begin{array}{c}- \\
.097\end{array}$ & $\begin{array}{c}.636 \\
* *\end{array}$ & 1 & & & & & \\
\hline NP & $\begin{array}{c}2.06 \\
63\end{array}$ & $\begin{array}{c}.507 \\
69\end{array}$ & .643 & $\begin{array}{c}.657 \\
* *\end{array}$ & $\begin{array}{l}.382 \\
* *\end{array}$ & $\begin{array}{c}- \\
.062\end{array}$ & $\begin{array}{l}.402 \\
* *\end{array}$ & $\begin{array}{l}.376 \\
* *\end{array}$ & 1 & & & & \\
\hline RDP & $\begin{array}{c}2.25 \\
57\end{array}$ & $\begin{array}{l}.808 \\
85\end{array}$ & .868 & $\begin{array}{l}.521 \\
* *\end{array}$ & .174 & $\begin{array}{c}- \\
.126\end{array}$ & .107 & .214 & $\begin{array}{l}.484 \\
* *\end{array}$ & 1 & & & \\
\hline IP & $\begin{array}{c}1.33 \\
73\end{array}$ & $\begin{array}{l}.206 \\
98\end{array}$ & .703 & $\begin{array}{c}.275 \\
*\end{array}$ & $\begin{array}{l}.341 \\
* *\end{array}$ & $\begin{array}{l}.290 \\
* *\end{array}$ & .072 & .198 & $\begin{array}{l}.586 \\
* *\end{array}$ & .171 & 1 & & \\
\hline BCB & $\begin{array}{c}1.41 \\
50\end{array}$ & $\begin{array}{c}.488 \\
68\end{array}$ & .915 & $\begin{array}{l}.673 \\
* *\end{array}$ & $\begin{array}{l}.450 \\
* *\end{array}$ & $\begin{array}{c}- \\
.235\end{array}$ & $\begin{array}{l}.609 \\
* *\end{array}$ & $\begin{array}{l}.491 \\
* *\end{array}$ & $\begin{array}{l}.665 \\
* *\end{array}$ & $\begin{array}{l}.461 \\
* *\end{array}$ & $\begin{array}{l}.0 \\
90\end{array}$ & 1 & \\
\hline BIO & $\begin{array}{c}1.48 \\
19 \\
\end{array}$ & $\begin{array}{c}.489 \\
93 \\
\end{array}$ & .845 & $\begin{array}{l}.722 \\
* * \\
\end{array}$ & $\begin{array}{l}.388 \\
* * \\
\end{array}$ & .025 & $\begin{array}{l}.447 \\
* * \\
\end{array}$ & $\begin{array}{l}.442 \\
* * \\
\end{array}$ & $\begin{array}{c}.537 \\
* * \\
\end{array}$ & $\begin{array}{c}.448 \\
* * \\
\end{array}$ & $\begin{array}{l}.1 \\
90 \\
\end{array}$ & $\begin{array}{l}.640 \\
* * \\
\end{array}$ & 1 \\
\hline
\end{tabular}

**. Correlation is significant at the 0.01 level (2-tailed).

*. Correlation is significant at the 0.05 level (2-tailed).

$\mathbf{F A C}=$ Facilities, $\mathbf{F I N}=$ Finance, $\mathbf{T R D}=$ Technology Research and Development, $\mathbf{S R D}=$ Sources of Research and Development, JRD=Joint R\&D, NP $=$ Network Opportunities, $\mathbf{R D P}=\mathrm{R}$ and $\mathrm{D}$ Projects, $\mathbf{I P}=$ Incubator Performance, $\mathbf{B C B}=$ Business Current Benefits, $\mathbf{B I O}=$ Business Incubator Objectives.

Table 5. Chi- square

\begin{tabular}{|c|c|c|c|c|c|c|c|c|c|c|}
\hline & FAC & FIN & TRD & SRD & JRD & NP & RDP & IP & $\overline{\text { BCB }}$ & BIO \\
\hline Chi-Square & 31.494 & 20.241 & 62.988 & 15.783 & 31.024 & 47.241 & 55.145 & 26.012 & 65.012 & 84.578 \\
\hline Df & 12 & 10 & 6 & 8 & 7 & 9 & 13 & 7 & 6 & 6 \\
\hline Asymp. Sig. & .002 & .027 & .000 & .046 & .000 & .000 & .000 & .001 & .000 & .000 \\
\hline
\end{tabular}

$\mathbf{F A C}=$ Facilities, $\mathbf{F I N}=$ Finance, $\mathbf{T R D}=$ Technology Research and Development, $\mathbf{S R D}=$ Sources of Research and Development, JRD=Joint R\&D, NP= Network Opportunities, $\mathbf{R D P}=\mathrm{R}$ and $\mathrm{D}$ Projects, $\mathbf{I P}=$ Incubator Performance, $\mathbf{B C B}=$ Business Current Benefits, BIO= Business Incubator Objectives.

Table 6. Model Summary

\begin{tabular}{cccccc}
\hline Model & R & R SquareAdjusted R SquareStd. Error of the EstimateDurbin-Watson \\
\hline 1 & $.807^{\mathrm{a}}$ & .651 & .608 & .12963 & 1.737 \\
\hline
\end{tabular}

a. Predictors: (Constant), Facilities, Finance, Technology R\& D, Sources of R \& D, Joint R\&D, Network opportunities, R\&D projects, Business current benefits, Business incubator objective

b. Dependent Variable: Incubator performance 
Table 7. ANOVA

\begin{tabular}{ccccccc}
\hline & & & & & & \\
Model & Sum of Squares Df & Mean Square & F & Sig. \\
\hline & Regression & 2.286 & 9 & .254 & 15.118 & $.000^{\mathrm{b}}$ \\
1 & Residual & 1.227 & 73 & .017 & & \\
& Total & 3.513 & 82 & & & \\
\hline
\end{tabular}

a. Dependent Variable: Incubator performance

b. Predictors: (Constant), Facilities, Finance, Technology R\& D, Sources of R \& D, Joint R\&D, Network opportunities, R\&D projects, Business current benefits, Business incubator objective.

Table 8. Coefficients

\begin{tabular}{|c|c|c|c|c|c|c|c|}
\hline \multirow[t]{2}{*}{ Model } & \multicolumn{2}{|c|}{$\begin{array}{l}\text { Unstandardized } \\
\text { Coefficients }\end{array}$} & \multirow{2}{*}{$\begin{array}{c}\begin{array}{c}\text { Standardized } \\
\text { Coefficients }\end{array} \\
\text { Beta }\end{array}$} & \multirow{2}{*}{$\mathbf{t}$} & \multirow{2}{*}{ Sig. } & \multicolumn{2}{|c|}{$\begin{array}{l}\text { Collinearity } \\
\text { Statistics }\end{array}$} \\
\hline & B & Std. Error & & & & Tolerance & VIF \\
\hline (Constant) & .050 & .179 & & .281 & .780 & & \\
\hline Facilities & -.013 & .050 & -.033 & -.257 & .798 & .282 & 3.545 \\
\hline Finance & .259 & .068 & .308 & 3.802 & .000 & .730 & 1.369 \\
\hline Technology R\& D & .282 & .078 & .323 & 3.627 & .001 & .602 & 1.661 \\
\hline Sources of R \& D & .061 & .055 & .137 & 1.097 & .276 & .307 & 3.256 \\
\hline Joint R\&D & .023 & .030 & .074 & .776 & .440 & .522 & 1.916 \\
\hline 1 Network opportunities & .349 & .042 & .856 & 8.287 & .000 & .449 & 2.229 \\
\hline R\&D projects & .014 & .024 & .054 & .577 & .566 & .540 & 1.850 \\
\hline Business current benefits & -.251 & .052 & -.592 & $-\overline{4}$ & .000 & .321 & 3.116 \\
\hline $\begin{array}{l}\text { Business incubator } \\
\text { objective }\end{array}$ & -.047 & .046 & -.112 & $1 . \overline{0} 4$ & .309 & .399 & 2.504 \\
\hline
\end{tabular}

Table 9. Public and Private Support

\begin{tabular}{|l|l|l|}
\hline \multicolumn{2}{|c|}{ Variables } & Yeale \\
\hline & 64 & 19 \\
\hline Government finance support available & 65 & 18 \\
\hline The financial support programmes & 74 & 9 \\
\hline Applied for a government grant & 61 & 22 \\
\hline Received any government grants & 66 & 17 \\
\hline Applied for a government loan & 68 & 15 \\
\hline Received one or more government loans startup & 63 & 20 \\
\hline Member of a Chambers of Commerce & 71 & 12 \\
\hline Visited the chamber of commerce & 65 & 18 \\
\hline Attended workshops, seminars or training programmes & & \\
\hline
\end{tabular}




\section{Discussion}

The analysis in this paper was performed to understand the opinion of startups in exemplifying the role of business incubators in sustaining their survival and growth. For ascertaining the role of business incubators, questions covering different variables such as facilities, services, achievements, and growth and survival were asked to startups located in seven incubators in Pakistan. Apart from the demographic and basic information about the startups, different variables were taken into consideration for the evaluation of the growth and survival of startups, which included facilities provided by the incubator, financial resources important and accessible for survival and growth, technology R\&D for producing new products and processes, sources of $R \& D$ and their impact on startups, public and private support, joint $R \& D$ projects with different universities, networking opportunities provided by the incubator, $R \& D$ projects to know the legitimate barriers of the networking opportunities, incubator performance, benefits of joining a current business incubator, and incubator objectives. To evaluate these variables, different analyses were applied, such as the mean value of all variables, reliability analysis, correlation analysis, regression analysis, and chi-square analysis. The study also shows the demographics of all respondents.

The first hypothesis is about the correlation analysis, which is partially accepted, as some variables have a significant relationship at $p<0.01$ and $p<0.05$ while some have an insignificant relationship. The second hypothesis is run to check the association between the variables, and the chi-square values indicate that the second hypothesis is accepted. To validate the third hypothesis, the regression analysis was applied between incubator performance and other remaining variables. The results show that the hypothesis is accepted as the values lies in the critical region.

Questions regarding whether the startup is receiving government support or any other private support are explained in Table 6 . The values mentioned in the current study reveal the results regarding the role of the incubators in sustaining the growth and survival of businesses. This information was directly sourced from startups that are currently incubated.

\section{Conclusion}

The focus of the current study was on identifying the effect of the different services and facilities provided by the incubator and how they affect the growth and survival of startups in Pakistan. Based on the findings and results, it can be concluded that different services provided by the incubator have a significant effect on the growth and survival of startups. Likewise, the relationship of incubator performance with reference to all other services provided by the incubator to startups is significant. Thus, incubator performance has a strong effect on the survival and growth of startups.

In a nutshell, business incubation is one of the tools that help create new opportunities for innovation and entrepreneurship, and is thus very helpful in sustaining the growth and survival of startups. Business incubators and technology business incubators are stapled with the potential to innovate and create knowledge, and consequently increase the number of overall innovations in the economy, thus helping the national economy make progress at the global level. The business incubation system in Pakistan is immature and mostly sponsored by the government. Political and legal pressure as well as insufficient finance are some of the common barriers faced by the incubation system in Pakistan. These hurdles are indirectly affecting the growth and survival of startups. However, the incubation process in the private sector is flourishing quite fast, with the new and young firms being provided with state-of-the-art facilities and services, thus contributing toward their survival and growth. 


\section{Limitations, Recommendation and Future Directions}

In the current study, only a few incubators in Pakistan are taken into consideration because of the time and cost constraints faced by the researcher. For better results and generalizability, other incubators in Pakistan can be considered as well.

This study would be helpful for business incubator managers. They will have guidelines to refer for improving their services and facilities. Accordingly, they will contribute toward societal upliftment, create job opportunities, and promote innovation and overall economic development of Pakistan.

Going forward, the researchers should focus on the government policies regarding business incubation in Pakistan. Following this quantitative study, case studies and interviews falling under qualitative research, specifically catering to the improvement of the incubation process, can prove very helpful. The current study covers cross-sectional research, whereas, in future, longitudinal research can be conducted for better results.

\section{Acknowledgement}

The authors are thankful to Northwestern Polytechnical University, NPU, Xi'an, and National Natural Science Foundation of China under Grant No. 2014JM9368.

\section{References}

[1] H. Sherman and D. S. Chappell, "Methodological challenges in evaluating business incubator outcomes", Economic Development Quarterly, vol. 12, no. 4, (1998), pp. 313-321.

[2] M. Brown, M. P. Harrell and W. Regner, "Internet Incubators: How to invest in the new economy without becoming as investment company", Business Lawyer, vol. 56, no. 1, (2000), pp. 273- 284.

[3] D. Monkman, "Business incubators and their role in job creation", President \& CEO National Business Incubation Association (NBIA), Athens, Ohio, (2010).

[4] NBIA, (2012).

[5] P. Kotler and K. KL, "Marketing management", vol. 12, (2006), pp. 181-183.

[6] L. Thobekani and R. K. Tengeh, "The Sustainability and Challenges of Business Incubators in the Western Cape Province, South Africa", Sustainability, vol. 7, no. 10, (2015), pp. 14344-14357.

[7] H. M. Neck and P. G. Greene, "Entrepreneurship education: known worlds and new frontiers", Journal of Small Business Management, vol. 49, no. 1, (2011), pp. 55-70.

[8] S. H. Timothy, "Small Business Management: Entrepreneurship and Beyond", Houghton Mifflin Company, Third edition, (2006).

[9] V. Chiesa and A. Piccaluga, "Exploitation and diffusion of public research: the case of academic spin-off companies in Italy", R\&D Management, vol. 30, no. 4, (2000), pp. 329-340.

[10] F. Schutte, "The University-Industry Relations of an Entrepreneurial University: the Case of the University of Twente", Higher Education in Europe, vol. 24, no. 1, (1999), pp. 47-65.1.

[11] S. A. Mian, "Assessing value-added contributions of university technology business incubators to tenant firms", Research policy, vol. 25, no. 3, (1996), pp. 325-335.

[12] N. Mahmood and C. Jianfeng, "Business Incubators: Boon or Boondoggle for SMEs and Economic Development of Pakistan", International Journal of U-\& E-Service, Science \& Technology, vol. 8, no. 4, (2015).

[13] S. M. Hackett and D. M. Dilts, "A real options-driven theory of business incubation", The Journal of Technology Transfer, vol. 29, no. 1, (2004), pp. 41-54.

[14] K. Aerts and P. Matthyssens, "Critical role and screening practices of European business incubators", Technovation, vol. 27, no. 5, (2007), pp. 254-267.

[15] http://www.nbia.org/resource_library/review/index.php

[16] "UKBI", What is Business Incubation? Retrieved 28.05.2015, from http://www.ukbi.co.uk, (2007).

[17] R. Lalkaka and J. Bishop, "Business incubators in economic development: an initial assessment in industrializing countries”, United Nations Development Programme New York, NY, (1996).

[18] P. H. Phan and D. S. Siegel, "Science parks and incubators: observations, synthesis and future research", Journal of Business Venturing, vol. 20, no. 2, (2005), pp. 165-182.

[19] P. A. Abetti, "Government-supported incubators in the Helsinki region, Finland: infrastructure, results, and best practices", The Journal of Technology Transfer, vol. 29, no. 1, (2004), pp. 19-40.

[20] R. Stuart and P. A. Abetti, "Start-up ventures: towards the prediction of initial success", Journal of Business Venturing, vol. 2, no. 3, (1987), pp. 215-230.

[21] A. Chandra and C. A. Chao, "Business incubator affiliation: impact on incubator funding and services", International Journal of Innovation and Regional Development, vol. 3, no. 6, (2011), pp. 551-572. 
[22] C. Campbell, "Change Agents in the New Economy: Business Incubators And E", Economic Development Review, vol. 7, no. 2, (1989), pp. 56.

[23] R. Petree and R. Petkov, "Technology Parks-Concept and Organization, Summary Report prepared for Center for Economic Development, Sofia", (1997).

[24] O. Adegbite, "Business incubators and small enterprise development: the Nigerian experience", Small Business Economics, vol. 17, no. 3, (2001), pp. 157-166.

[25] M. V. Zedtwitz, "Classification and management of incubators: aligning strategic objectives and competitive scope for new business facilitation", International Journal of Entrepreneurship and Innovation Management, vol. 3, no. 1-2, (2003), pp. 176-196.

[26] H. M. A. Mubaraki, and M. Busler, "Business incubation as an economic development strategy: a literature review", International Journal of Management, vol. 30, no. 1, (2013), pp. 362.

[27] D. A. Lewis, "Business Incubators and Their Role in Job Creation", U.S. House of Representatives Committee on Small Businesses Retrieved October 25th, 2010, from http://www.house.gov/smbiz/hearings/hearing-3-17-10-businessincubators/Lewis.pdf, (2010).

[28] L. Tornatzky H. Sherman and D. Adkins, "Incubating Technology Businesses: A National Benchmarking Study”, Athens, Ohio: National Business Incubation Association, (2003).

[29] R. Grimaldi and A. Grandi, "Business incubators and new venture creation: an assessment of incubating models", Technovation, vol. 25, no. 2, (2005), pp. 111-121.

[30] M. Stefanović and G. Devedžić, "Incubators in Developing Countries: Development Perspectives", (2008).

[31] I. C. MacMillan and L. Zemann, "Criteria distinguishing successful from unsuccessful ventures in the venture screening process", Journal of Business Venturing, vol. 2, no. 2, (1987), pp. 123-137.

[32] R. W. Smilor, "Managing the incubator system: critical success factors to accelerate new company development", Engineering Management, IEEE Transactions on, no. 3, (1987), pp. 146-155.

[33] R. H. Keeley, and J. B. Roure, "Management, strategy, and industry structure as influences on the success of new firms: A structural model", Management science, vol. 36, no. 10, (1990), pp. 1256-1267.

[34] E. B. Roberts, "Entrepreneurs in high technology: Lessons from MIT and beyond", Oxford University Press, (1991).

[35] N. Somsuk, and T. Laosirihongthong, "A fuzzy AHP to prioritize enabling factors for strategic management of university business incubators: Resource-based view", Technological Forecasting and Social Change, vol. 85, (2014), pp. 198-210.

[36] F. Jamil, K. Ismail and N. Mahmood, "A review of commercialization tools: University incubators and technology parks", International Journal of Economics and Financial Issues, vol. 5, no. 1, (2015). 
International Journal of Multimedia and Ubiquitous Engineering Vol.12, No.1 (2017) 